\title{
Influence of geographical distribution, body size and diet on population density of benthic fishes off Namibia (South West Africa)
}

\author{
Enrique Macpherson \\ Instituto de Ciencias del Mar, Paseo Nacional s/n, 08003 Barcelona, Spain
}

\begin{abstract}
This study supports the hypothesis that species tend to become rarer towards the limits of their geographic distribution. Over-all species abundance is positively correlated with the size of the area occupied. However, body size is a weak predictor of the abundance of benthic fish species. It is suggested that habitat complexity, competition or other factors regulate patterns of species abundance.
\end{abstract}

\section{INTRODUCTION}

Search for regularities in the structure of animal communities is one of the main goals of ecology (e.g. Andrewartha \& Birch 1954). Most of the patterns so far described have been derived from the study of the relation between abundance and geographical distribution, and body size (e.g. Williams 1964, Peters 1983, Brown 1984, Brown \& Maurer 1987, Gotelli \& Simberloff 1987). The relation between species abundance and geographic distribution (Hanski 1982, Bock \& Ricklefs 1983, Brown 1984, Bock 1987) shows 2 important generalities: (1) a decrease in population density from the center to the limits of their distribution; (2) a positive correlation between density and distributional range. In addition, several studies revealed a negative relation between population density and body size (Damuth 1981, Peters 1983, Peters \& Raelson 1984, Juanes 1986, Robinson \& Redford 1986). Most of these relationships have been described for terrestrial communities; whether or not they can be extended to fish communities is largely unknown. The verification of these relationships for fish would, therefore, increase their generality.

Fish communities differ from most terrestrial communities in 2 important ways: (1) Fish communities occupy a 3-dimensional habitat with both horizontal and vertical heterogeneity; (2) the wide ranges in body size for many fish species are associated with a large ecological niche (Ross 1986 and references cited therein). Because both habitat heterogeneity (Juanes
1986) and diet (Peters 1983, Peters \& Wassemberg 1983, Peters \& Raelson 1984, Robinson \& Redford 1986) can significantly influence size-density relations, the examination of such relationships for fish communities is an important subject.

The decrease in abundance of species toward their distribution limits (Brown 1984) may confound the interpretation of the relation between body size and population density. Since most marine fishes occupy very broad areas, the location of a given population relative to its distributional range must be considered in any study of abundance.

Here, I examined the influence of geographic distribution, body size, and diet on the densities of fish species off the coast of Namibia (South West Africa) $\left(17^{\circ}\right.$ to $\left.28^{\circ} \mathrm{S}\right)$. In order to be able to compare my results to previous research, based on areal densities of terrestrial organisms, I chose to study benthic fish, for which the definition of an areal density is straightforward.

\section{STUDY AREA AND CENSUS METHOD}

Two well-defined biogeographical provinces meet at the Namibian coast: a tropical fauna and a temperate fauna of South African origin (Lloris 1986). The study area experiences important upwelling phenomena which have a major influence on its biotic constituents and which act as a natural barrier between the 2 faunas. 
Trophic groups of the benthic fish community are well defined (Macpherson \& Roel 1987, Macpherson unpubl.). The community comprises species that feed on the bottom (i.e. benthic species), and others that feed some distance over the bottom (i.e. benthopelagic species). These groups can be subdivided further with respect to the nature of their prey. Benthopelagic species consume pelagic crustaceans (pelagic crustacean predators, PCP), myctophids, and cephalopods (myctophid and cephalopod predators, MCP). Benthic predators can be divided into polychaetes and copepods (PP), benthic crustaceans (decapods) (BCP), and predators of benthic fish (BFP). Those species showing a wide distribution in the water column were excluded from the analysis, because they could not be sampled efficiently with benthic trawls. The changes in size which fish experience during ontogeny are associated with corresponding changes in trophic habits. Since diet is believed to have a strong influence on the relationship between species density and individual size and distribution, I considered different size classes within a species, which differed in trophic habit to be separate units of analysis. For simplicity I shall refer hereafter to each of the 101 units of analysis as 'species' (Table 1).

The study area covered the coast off Namibia (South West Africa), lying between $17^{\circ} \mathrm{S}$ and $28^{\circ} \mathrm{S}$ in water depth of 100 to $800 \mathrm{~m}$ (ca 50000 miles $^{2}$ ). The area was subdivided into 72 blocks each comprising $1 \times 100 \mathrm{~m}$ depth strata. Fish census data were obtained using benthic trawls during 7 cruises from 1980 to 1984 (for details see Macpherson \& Roel 1987). Each block was sampled during at least 2 cruises (summer and winter), each sample comprising 2 to 10 trawls according to block size. Within each block, I calculated the total weight and counted the individuals of each species. Estimates from all blocks were then combined to yield average body weight and density for the different species.

I used correspondence analysis (Benzecri 1980) to examine the patterns of variation of species abundance in relation to its geographical distribution. Correspondence analysis, also known as reciprocal analysis (Hill 1973), has the advantage of providing a dual representation of variables and descriptors in a common system of orthogonal axes. In this representation, it will be possible to observe groups of variables with similar descriptors and, reciprocally, it will be possible to observe a particular descriptor close to a group of variables where it is well represented; for instance, where the abundance of each species (variable) is associated with latitude (descriptor), the analysis places species densities in rows and latitudes in columns. In this analysis I excluded cosmopolitan species and very rare species $\left(<1\right.$ ind. swept mile $\left.^{-1}\right)$, for which the definition of distributional area is difficult. Therefore, I only considered 37 species, for which the geographical endpoint of their range distribution was within the study area (Table 1). The association between mean density of a species within blocks where it occurred and the number of blocks in which it was present, was assessed using Pearson correlation coefficients $(r)$. Because previous studies have shown that density is a power function of body size (e.g. Peters 1983, Juanes 1986, Robinson \& Redford 1986), I used the following equation to quantify this relationship:

$\log$ density $=a+b \log$ weight

\section{RESULTS AND DISCUSSION}

\section{Geographical patterns in species abundance}

Interpretation of correspondence analysis is based primarily on the results presented in Fig. 1. The 2 first factorial axes explain $78 \%$ of the variability of the contingency table formed with the data. The analysis showed that the data were arranged in a clear parabolic form. As several authors (e.g. Benzecri 1980) pointed out, a parabolic curve both in correspondence and principal components analysis, signifies a clear gradient. In this case, the gradient is the result of a positive relationship between species abundance and size of the specie's latitudinal distribution. The first axis (F1) was closely related to latitude (Fig. 1), and discriminated between two groups of species: southern (A in Fig. 1) and northern species (B in Fig. 1) (see also Table 1). The other species are more wide by distribution. The second axis (F2) was a function of the first,

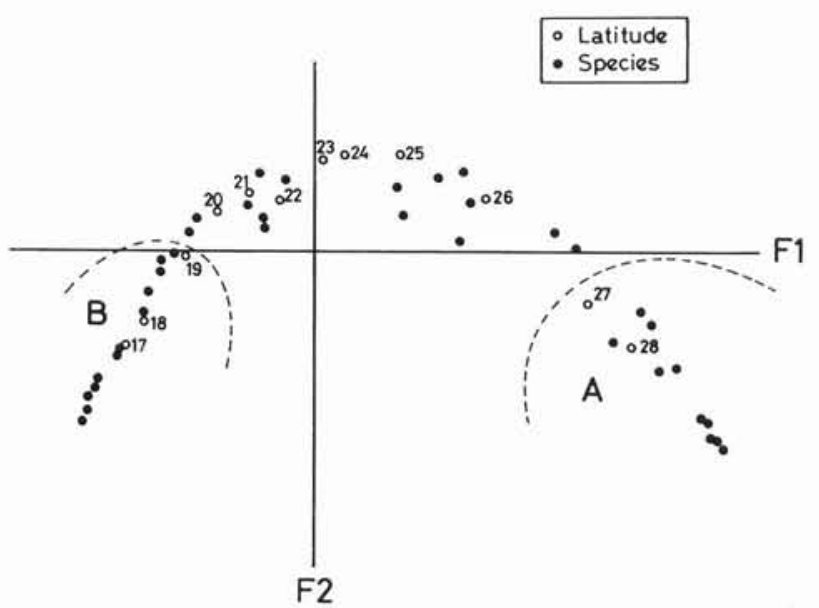

Fig. 1. Correspondence analysis of the matrix of species abundances and latitude. Species considered are those for which the geographical endpoint of their range distribution was within the study area (Table1). (A) Southern species; (B) northern species 
Table 1. List of the 101 species by trophic group. (A) Southern species; (B) northern species; see also text and Fig. 1

Pelagic crustacean predators (PCP)

- Alepocephalus rostratus

Apristurus nasatus

Beryx splendens

-B Clorophthalmus atlanticus

-B Dentex macrophthalmus

Epigonus denticulatus

Epigonus telescopus

Hoplostethus atlanticus

- Hoplostethus cadenati

Howella sherboni

- Lamprogrammus exutus

- A Malacocephalus laevis

- Malacocephalus occidentalis

Merluccius capensis $(10-39 \mathrm{~cm})$

:A Merluccius paradoxus $(10-30 \mathrm{~cm})$

Platyberyx groenlandicus

Scopeloberyx robustus

Selachophidium guentheri

-B Synagrops microlepis

Tetragonurus cuvieri

Myctophid \& cephalopod predators (MCP)

Allocyttus verrucosus

Centrophorus squamosus

Centrophorus uyato

Centroscyllium fabricii

Centroscymnus crepidater

Chlamydoselachus anguineus

Deania calceus

- Etmopterus lucifer

Etmopterus pusillus

- Galeus polli

Heptranchias perlo

Hexanchus griseus

- A Holohalaelurus regani

Merluccius capensis (40-59 cm)

- Merluccius paradoxus (40-69 cm)

- Neocyttus rhomboidalis

Oxynotus centrina

-A Scyliorhinus capensis

Scymnodon obscurus

Squalus acanthias

Squalus blainvillei

Trachyrhynchus scabrus (> $30 \mathrm{~cm}$ )

Polychaete \& copepod predators (PP)

Austroglossus microlepis

Bathylagus glacialis

- B Bromisculus imberbis

Careproctus griseldea

-B Coelorhynchus coelorhynchus

Coelorhynchus fasciatus $(10-39 \mathrm{~cm})$

- A Coelorhynchus occa

- A Cynoglossus capensis
Dicrolene intronigra

Ebinania costacanariae

Guentherus altivela

Holosaurus ovenii

- A Mahia matamua

Nezumia aequalis

- A Nezumia longibarbatus

Notacanthus sexspinis

- A Paracallionymus costatus

Physiculus capensis

- B Pterothrissus belloci

Raja confundens $(10-29 \mathrm{~cm})$

Raja leopardus

Raja straeleni $(20-29 \mathrm{~cm})$

Trachyrhynchus scabrus $(10-29 \mathrm{~cm})$

Trypterophycis gilchristii

Benthic crustacean (decapod) predators (BCP)

*A Callorhynchus capensis

- Chatrabus damaranus

-A Chelidonyctis capensis Chelidonyctis queketti

- Coelorhynchus fasciatus $(>40 \mathrm{~cm})$

Coloconger cadenati

Congiopodus torvus

Ebinania costacanariae $(>10 \mathrm{~cm})$

Gnatophis capensis

- Helicolenus dactylopterus (10-39 cm)

-B Laemonema laureysi

Mystriophis crosnieri

Ophichthus rufus

-B Pontinus leda

Raja confundens (>30 cm)

Raja doutrei $(50-69 \mathrm{~cm})$

Raja miraletus

Raja straeleni (>30 cm)

Synaphobranchus kaupi

Torpedo nobiliana

Trachyscorpia capensis

-B Trigla lyra

Benthic fish predators (BFP)

Bathyuroconger vicinus

Cruriraja parcomaculata

Echelus pachyrhynchus

- Genypterus capensis

- Helicolenus dactylopterus (>30 cm)

Japonoconger africanus

- Lophius upsicephallus

-B Lophius vaillanti

Merluccius capensis ( $>60 \mathrm{~cm})$

- Merluccius paradoxus $(>70 \mathrm{~cm})$

-B Merluccius polli

Neoharriotta pinnata

Raja doutrei $(>70 \mathrm{~cm})$

- Species for which the geographical endpoint of their range was within the study area

hence it is difficult to interprete. These results support the contention of Brown (1984), in that species tend to become rarer towards their distribution limits.

Species abundance was also positively correlated with the number of blocks occupied (Table 2). In agree- ment with previous results (Hanski 1982, Bock \& Ricklefs 1983, Brown 1984, Bock 1987), these correlations were still present after the data were pooled together into groups of closely related species (i.e. those in the same trophic class). The only exceptions to this pattern 
Table 2. Correlations between size of the species' geographic range (number of occupied sites) and mean within-range abundance

\begin{tabular}{|lrrr|}
\hline Dietary category & $n$ & $r$ & \multicolumn{1}{c|}{$p$} \\
\hline All species & 101 & 0.508 & $<0.001$ \\
Predators of & & & \\
$\quad$ Pelagic crustaceans (PCP) & 20 & 0.677 & 0.001 \\
Myctophids \& cephalopods (MCP) & 22 & 0.737 & $<0.001$ \\
Polychaetes \& copepods (PP) & 24 & 0.516 & 0.009 \\
Benthic crustaceans (BCP) & 22 & 0.499 & 0.012 \\
Benthic fishes (BFP) & 13 & 0.299 & 0.323 \\
\hline
\end{tabular}

were the predators of benthic fishes, for which no significant correlations were observed. The lack of correlation for this group is not surprising since predators of benthic fishes comprise the most diverse array of species and collectively are the trophic group with the smallest level of similarity (Macpherson \& Roel 1987). Predators also have the largest body sizes and ingest, therefore, a wide range of prey size and types (Macpherson 1983a).

\section{Relation between density and body size}

The average relation between density and body size for the different species was significant $(p<0.0001)$ but weak ( $r=0.37$; Fig. 2, Table 3 ). The weakness of this relation may be the result of the diverse range of trophic habits included in the data set. Consequently, I tested whether the variance of density or body size could better be explained by considering trophic habit as well. The relationship between density and size was significant for only the pelagic crustacean predators ( $r=0.72 ; p=0.0004)$, and the benthic crustaceans predators $(r=0.52 ; p<0.01)$ (Table 3 , Fig. 2$)$. The weakness of these relationships may be due to species $(n=37)$ in the census data which were near the limits of their geographical distribution and which were therefore rare. This factor, however, does not appear to be important because the strength of the relationships did not increase by excluding such species from the analysis (Table 3).

The slope of the relation for pelagic crustacean predators (PCP) was steeper than that for benthic crustacean predators (BCP) (Table $3, p<0.05$ only for $\mathrm{B}$ ). Benthopelagic species have a more restricted diet than benthic species which ingest both benthic and occasionally benthopelagic prey (Macpherson 1983a). The difference in slopes supports the idea that a steeper slope in the size-density relation is associated with a more flexible resource exploitation (Juanes 1986, Robinson \& Redford 1986).

The weakness of the size-density relationship for benthic fishes is qualitatively similar to the results obtained for bird communities (Juanes 1986). Both these groups occupy (or use resources from) a more heterogeneous environment than other groups with 2dimensional habitats (e.g. mammals). Since the sizedensity relationship appears to reflect a problem of spatial 'packing' of the species, it is reasonable to expect that species which inhabit a more complex environment should show a weaker relation between body size and population density than species which live on a simpler habitat (Peters \& Raelson 1984, Juanes 1986, Robinson \& Redford 1986).

Table 3. Statistics describing the relation of log body size $(\mathrm{g})$ and log density (fishes/swept mile) for all species and trophic groups

\begin{tabular}{|c|c|c|c|c|c|c|c|c|c|}
\hline $\begin{array}{l}\text { Dietary } \\
\text { category }\end{array}$ & & $n$ & $\mathrm{a}$ & $\begin{array}{c}95 \% \\
\text { c.l. }\end{array}$ & b & $\begin{array}{c}95 \% \\
\text { c.l. }\end{array}$ & $r$ & $p$ & $\mathrm{Ra}$ \\
\hline \multirow[t]{2}{*}{ All species } & A & 101 & 1.92 & 0.86 & -0.70 & 0.34 & 0.37 & 0.0002 & $6-6457$ \\
\hline & B & 64 & 0.85 & 1.17 & -0.41 & 0.45 & 0.22 & 0.069 & $10-6457$ \\
\hline \multirow[t]{2}{*}{ PCP } & $\mathrm{A}$ & 20 & 6.66 & 2.88 & -2.83 & 1.35 & 0.72 & 0.0004 & $9-501$ \\
\hline & B & 11 & 9.32 & 4.81 & -4.23 & 2.14 & 0.83 & 0.002 & $32-501$ \\
\hline \multirow[t]{2}{*}{ MCP } & A & 22 & 2.54 & 2.66 & -0.84 & 0.91 & 0.40 & 0.066 & $45-6457$ \\
\hline & B & 16 & 2.05 & 3.17 & -0.71 & 1.06 & 0.34 & 0.172 & $45-6457$ \\
\hline \multirow[t]{2}{*}{ PP } & A & 24 & 0.76 & 1.63 & -0.18 & 0.86 & 0.09 & 0.673 & $6-575$ \\
\hline & B & 16 & 0.22 & 2.06 & -0.08 & 1.04 & 0.04 & 0.867 & $10-575$ \\
\hline \multirow[t]{2}{*}{$\mathrm{BCP}$} & A & 22 & 2.88 & 2.20 & -1.20 & 0.86 & 0.52 & 0.0085 & $63-3020$ \\
\hline & B & 14 & 1.10 & 3.60 & -0.67 & 1.30 & 0.32 & 0.281 & $63-3020$ \\
\hline \multirow[t]{2}{*}{ BFP } & $\mathrm{A}$ & 13 & -1.88 & 3.11 & 0.61 & 1.02 & 0.37 & 0.213 & $120-4074$ \\
\hline & B & 7 & -3.92 & 3.53 & 1.20 & 1.17 & 0.72 & 0.045 & $120-4074$ \\
\hline
\end{tabular}

(A) All species, (B) excluding species for which the geographical end point of their range was within the study area. PCP: pelagic crustacean predators; MCP: myctophid \& cephalopod predators; PP: polychaete \& copepod predators; BCP: benthic crustacean predators; BFP: benthic fish predators. Body size $=$ independent variable; $n=$ number of species; intercept and 95 $\%$ confidence limits; $\mathrm{b}=$ slope with $95 \%$ confidence limits (c.1.); $r=$ correlation coefficient; $p=$ probability that the correlation coefficient is significant; $\mathrm{Ra}=$ range of (linear) values of body size in $\mathrm{g}$ 


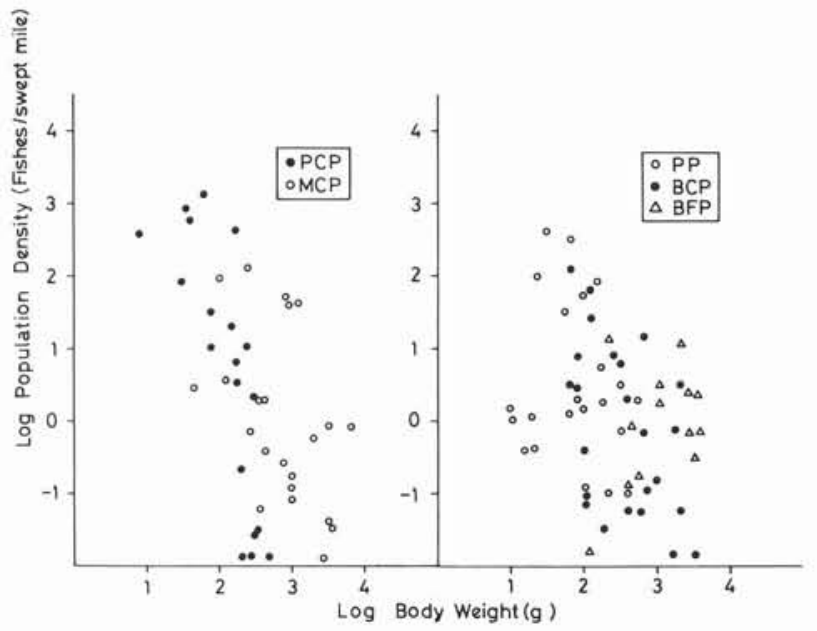

Fig. 2. Relation between log body weight and log population density. PCP: pelagic crustacean predators; MCP: myctophid \& cephalopod predators; PP: polychaete \& copepod predators; BCP: benthic crustacean (decapod) predators; BFP: benthic fish predators. For statistics describing each regression, see Table 3

The differences among the trophic classes in the correlations between both variables, may partially reflect differences in the degree of coupling between the species and the locally available resources. The absence of any size-density relations for predatory of myctophids and cephalopods and predators of benthic fish may, therefore, be the result of their variable weak dependence on local resources or both. These species are generally large and, therefore, ingest a wide size range of prey (Macpherson 1983a). Moreover, predators of myctophids and cephalopods are largely selaceans that accumulate a good proportion of the energy ingested as reserves (Springer 1969), and the predators of benthic fishes vary widely in their hunting strategies (from ambush predators to actively pursuing species; Macpherson 1983a, b, Roel \& Macpherson 1988).

In summary, body size is a weak predictor of the abundance of benthic fish species. This result supports existing evidence which points to habitat complexity as a major determinant of the degree of association between the size and the densities of animals within a community (Juanes 1986). In these communities, species abundance is only weakly associated with body size, and other factors - such as competition, predation, behaviour, and environmental conditions - must play a more important role in determining general patterns of species abundance.

Acknowledgements. I thank C. Duarte for invaluable help in the preparation of the manuscript. M. Barange, J. Lleonart, M. P. Olivar, A. Gordoa, J. M. Gili and I. Uriz criticized and improved the manuscript.

\section{LITERATURE CITED}

Andrewartha, H. G., Birch, L. C. (1954). The distribution and abundance of animals. University of Chicago Press, Chicago

Benzecri, J.-P. (1980). L'analyse des données. II, l'analyse des correspondences, 3rd edn. Dunod, Paris

Bock, C. E. (1987). Distribution-abundance relationships of some Arizona landbirds: a matter of scale? Ecology 68: $124-129$

Bock, C. E., Ricklefs, R. E. (1983). Range size and local abundance of some North American songbirds: a positive correlation. Am. Nat. 122: 295-299

Brown, J. H. (1984). On the relationship between abundance and distribution of species. Am. Nat. 124: 255-279

Brown, J. H., Maurer, B. A. (1987). Evolution of species assemblages: effects of energetic constraints and species dynamics on the diversification of the North American avifauna. Am. Nat. 130: 1-17

Damuth, J. (1981). Population density and body size in mammals. Nature, Lond. 290: 699-700

Gotelli, N. J., Simberloff, D. (1987). The distribution and abundance of tallgrass prairie plants: a test of the coresatellite hypothesis. Am. Nat. 130: 18-35

Hanski, I. (1982). Dynamics of regional distribution: the core and satellite species hypothesis. Oikos 38: 210-221

Hill, M. O. (1973). Reciprocal averaging: an eigenvector method for ordination. J. Ecol. 61: 237-249

Juanes, F. (1986). Population density and body size in birds. Am. Nat. 128: 921-929

Lloris, D. (1986). Ictiofauna demersal y aspectos biogeograficos de la costa sudoccidental de Africa (SWA/ Namibia). Monogr. Zool. Mar. 1: 9-432

Macpherson, E. (1983a). Ecologia trofica de peces en las costas de Namibia. Res. Exp. Cient. 11: 81-137

Macpherson, E. (1983b). Feeding pattern of the kingklip (Genypterus capensis) and its effect on the hake (Merluccius capensis) resource off the coast of Namibia. Mar. Biol. 78: 105-112

Macpherson, E., Roel, B. (1987). Trophic relations in the demersal fish community off Namibia. S. Afr. J. mar. sci. 5: 585-596

Peters, R. H. (1983). The ecological implications of body size. Cambridge University Press, Cambridge

Peters, R. H., Raelson, J. V. (1984). Relations between individual size and mammalian population density. Am. Nat. 124: 498-517

Peters, R. H., Wassenberg, K. (1983). The effect of body size on animal abundance. Oecologia (Berl.) 60: 89-96

Robinson, J. G., Redford, K. H. (1986). Body size, diet, and population density of Neotropical forest mammals. Am. Nat. 128: 665-680

Roel, B., Macpherson, E. (1988). Feeding of Merluccius capensis and $M$. paradoxus off Namibia. S. Afr. J. mar. sci. 6: $227-243$

Ross, S. T. (1986). Resource partitioning in fish assemblages: a review of field studies. Copeia 1986: 352-388

Springer, S. (1969). Social organization of shark populations. In: Gilbert, P. W., Matheuson, R. F., Rall, D. P. (eds.) Sharks, skates, and rays. The Johns Hopkins Press, Baltimore, p. 149-174

Williams, C. E. (1964). Patterns in the balance of nature and related problems in quantitative ecology. Academic Press, New York 